




\section{HISTORISK SAMFUND FOR SØNDERJYLLAND}

henleder opmærksomheden pâ sine nyere publikationer, hvoraf føIgende er udsendt i 1965 :

Jacob Fabricius d. Yngres Optegnelser.

Tekst, oversattelse og noter ved pastor emer. A. Andersen, 477 sider. Iudb. $\mathrm{kl}$. $30,00(60,00)$.

Andreas $\emptyset$ ster:

Barn i Merrnhuternes Christiansfeld, 170 sider.

Indb. $\mathrm{kr} .6,00(12,00)$.

f'ortegnelse over samtlige publikationer findes sidst $i$ ârbogen, hvoriblandt flere gode gaveideer, bl, a.:

Jørgen Paulsen og Poul Kürstein :

Sønderjylland. Historisk Billedbog.

Indb. kr. $15,00(30,00)$.

1. oplag (15.000 ekspl.) Ud solgt.

2. oplag (5000 ekspl.) Et lille restoplag haves endnu.

Frederik Høyberg:

Gennem 80 ir.

Indb. kr. 5,50 $(11,00)$.

Priserne i parentes er bogladepriser. Det kan betale sig at vare medlem af Fistorisk Samfund.

Begerne fåes ved henvendelse til:

\section{HISTORISK SAMFUND \\ FOR SøNDERJYLLAND}

Ekspeditionen

adr.: Landsarkivet . Abenră.

Abonnement på Sønderjysk Mânedsskrift ka1l tegnes sammesteds og koster $20,00 \mathrm{kr}$. årligt eller $10,00 \mathrm{kr}$. halvårligt.

Provenumre tilsendes gratis på forlangende.

Omslagsbilledet:

Sandbjerg Slot i luftperspektiv.

(Fot.: Sylvest Jensen, Hillerød). 
H. P. Clausen: Dansk og tysk på Als 1812-48 I ...... side

Peter Kr. Iversen: Lærer Alfred Torps optegnelser fra et

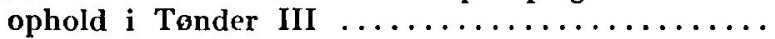

Kaj Rolisen Nissen: Problemer omkring >Præsident Topff

Jens Holdt: Breve fra Jørgen Iversen til Rasmus Clausen i årene 1889-1903 . . . . . . . . . . . . . .

Aage Trommer: Modstandsbevægelsen i Åbenrå og omegn

Urban Schroder: Lojt-degnen Hans Mikkelsen som salmedigter og andre iagttagelser over et håndskrevet

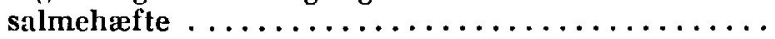

Holger Hjelholdt: Palmerstons mæglingsforslag - 19. maj og 23. juni 1848 i den dansk-tyske strid ........

F. Matzen: Historien om en gammel kanon .........

Knud A. Rasmussen: Ny litteratur om $1864 \ldots \ldots \ldots \ldots$

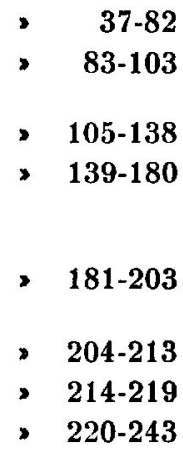

Geschichte Schleswig-Holsteins (ved Johan Hvidt-

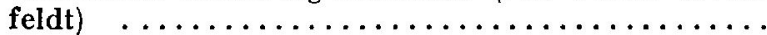

Kegnæs 1615-1965. Træk af Kegnæs sogns historie (ved Peter Kr. Iversen) $\ldots \ldots \ldots \ldots \ldots \ldots \ldots \ldots$ Jorgen Mågåd: Tysk fangelejr i Danmark (ved Johan Hvidtfeldt) $\ldots \ldots \ldots \ldots \ldots \ldots \ldots \ldots \ldots$ Jacob Fabricius den Yngres Optegnelser 1617-1644

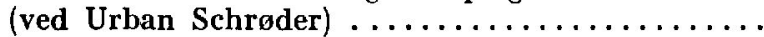
Frederik Hoyberg: Gennem 80 Ảr. Erindringer fra fremmedherredommets tid (ved Morten Kamphövener

, 244-248

, 248-250

251-252

, 252-257

, 258-260

Bognyt (ved Olav Christensen, Peter Kr. Iversen og Morten Kamphövener) ..................

, 261-264

Noter og nyt:

Axel Linvald - Landsarkivet - Haderslev Amts Museum - Ảbenrå Museum - Museet på Sønderborg sIot - Tonder Museum - Restaureringen af Sonderborg slot - Den store egnsvandring - Kirkehistorisk samlag - Nordfriisk Instituut - Båndoptagelser og arkivalier til sangens historie i Sonderjylland - Amtskredsenes arbejde ..........

, 265-284

Ársberetning og regnskab 1964-65 (ved Peter Kr. Iversen og Olav Christensen) $\ldots \ldots \ldots \ldots \ldots \ldots \ldots \ldots \ldots$

Tillog til medlemsfortegnelsen ................ Fortegnelse over skrifter m. v., udgione af Historisk Sam-

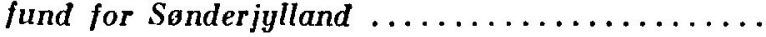

, 285-290

\292-296

, 297-298 
